\title{
The decline and probable extinction of the Colombian Grebe Podiceps andinus
}

\author{
J. FJELDS $\AA$
}

\begin{abstract}
Summary
Searches were made for the Colombian Grebe Podiceps andinus in 1981 in the wetlands in the Eastern Andes of Colombia. The studies also included surveys of other waterbirds and recorded the general conditions of these wetlands, once the stronghold for waterbirds in the northern Andes. The Colombian Grebe was apparently last seen in 1977 in Lake Tota, and is probably extinct, although a flock may have been moving around outside Lake Tota and could have settled outside the former breeding area. The primary reason for the decline must be draining of wetlands and eutrophication and siltation which destroyed the open submergent Potamogeton vegetation, where this grebe may have been feeding on a large diversity of arthropods. Introduction of exotic fish and hunting may also have played a role.
\end{abstract}

Durante 1981 se han realizado varias expediciones en busca de Podiceps andinus en las zonas húmedas de los Andes Orientales de Colombia. Durante estos estudios también se censaron otras aves acuáticas y se tomaron notas sobre el estado general de éstas zonas húmedas, que en el pasado fueron el principal enclave para las aves acuáticas en los Andes del Norte. Aparentemente Podiceps andinus fué visto por última vez en 1977 en el Lago Tota, y está probablemente extinguido, aunque podría haber un bando en las inmediaciones de dicho lago que se haya establecido fuera de la antigua área de cría. La razón fundamental del declive debe ser el drenaje de las zonas húmedas y la eutrofización y salinización que ha destruido la vegetación sumergida de Potamogeton, donde ésta especie se alimentaba de una gran variedad de artrópodos. La introducción de peces exóticos y la caza pueden haber influido también.

\section{Introduction}

The Colombian Grebe Podiceps andinus has been known from the Bogotá wetlands in Cundinamarca in the Eastern Andes of Colombia since around 1920 (Meyer de Schauensee 1948-1952, Olivares 1959). Being in transitory plumages, the early specimens were assumed to be visiting Black-necked Grebes P. nigricollis from the Nearctic. In 1945 Borrero (1947) discovered that the bird was resident on Lake Tota in the province of Boyacá. He was preparing its description as a subspecies andinus of $P$. nigricollis (J. I. Hernández C., pers. comm.) when Meyer de Schauensee (1959) described it, under the same name as planned by Borrero, and on the basis of two of Borrero's specimens plus an older specimen from Sabana de Bogotá.

Opinions about the taxonomic rank of andinus have varied (Simmons 1962, Blake 1977, Storer 1979). Its colours (described below) may appear to represent 
primitive character states compared with those of typical $P$. nigricollis, as well as the more southern derivates Silvery and Junín Grebes $P$. occipitalis and taczanowskii (Fjeldså 1985: 100; the published phylogeny should be tested using DNA from existing specimens). In the light of the recent tendency towards giving species rank to distinctive evolutionary units, binomial treatment is used in this paper.

Colombian ornithologists had for a long time been aware of the alarming decline of the rich avifauna of the Bogotá wetlands and the disappearance of the endemic grebe (Campezano 1960, Borrero 1963). On the basis of recent information from R. S. Ridgely, King (1978-1979) judged that very few birds remained. This was my motive for searching for this grebe in 1981 (SeptemberOctober), and this was followed by an ICBP expedition in July-August the following year. The ICBP report (Varty et al. 1985) focused mainly on the birds of the reed-swamps, as they concluded that the Colombian Grebe had been "extinct for perhaps 20 years" and that the area had lost its value for open-water birds. Because of their rather brief account of the demise of the endemic grebe, I here publish the results of my own study, some of which have already been used in the account of the bird in Collar et al. (1992).

\section{A brief history of the state of the wetland habitats of the Eastern Andes}

The savannas which today cover the Bogotá Plateau $\left(1,150 \mathrm{~km}^{2}\right)$ and Ubaté Plateau $\left(650 \mathrm{~km}^{2}\right)$ at 2,600 $\mathrm{m}$ in the department of Cundinamarca in the Eastern Cordillera of Colombia were formed as large lakes dammed by geological tilting in the Pliocene. These lakes were gradually filled with sediments to become mosaics of shallow weedy lakes, marshes and swamps (van Geel and van der Hammen 1973, Hooghiemstra 1991). These wetlands became the stronghold for waterbirds in the northern Andes, with several endemic taxa (Fjeldså 1985), including the Colombian Grebe.

The wetlands were still enormous by the time of the Conquista, but have now been drained almost completely and turned into pastureland, water-consuming greenhouse industries and Eucalyptus plantations. Only a few small marshy areas remain on the Bogotá Plateau, most of them totally overgrown by tall Scirpus californicus or Typha latifolia vegetation, or strongly polluted by sewage or siltation caused by soil erosion in the surrounding hills. Floating-leaf plants such as Azolla filiculoides, Bidens laevis and Limnobium stoloniferum now cover most of the water surfaces of the small remaining lakes. The shallowing and overgrowing eventually encourages further drainage. Ironically, Colombia's capital Santa Fe de Bogotá, established on the edge of a former wetland, now has insufficient water supply! New water tanks or larger reservoirs constructed in the adjacent valleys (Embalses del Muña, Neusa and Tominá and Represa de Sisga) are unsuitable for waterbirds because of the unstable water levels and siltation. The waterbirds have also suffered from indiscriminate egg-collecting and hunting.

Currently, Lake Tota, situated at 3,040 $\mathrm{m}$ in the department of Boyacá, is the only larger lake in the Eastern Andes that still supports significant populations of waterbirds. This lake is $56.2 \mathrm{~km}^{2}$ large, with an average depth of $34 \mathrm{~m}$. However, because of use of water for mining activities the lake levels have 
fluctuated up to $2 \mathrm{~m}$, and have been permanently lowered $1 \mathrm{~m}$ since 1950 to create new agricultural areas (CAR 1978). The large shallows that once existed outside Aquitania on the eastern shore were then turned into meadows which were densely ditched to permit cultivation except on the fen-like areas in the transition towards the reed-swamp. Up to 1962 the main crop was potatoes, but this has been almost entirely replaced by commercial production of onions on the fertile plains for maximal exploitation of the minifundios (smallholdings). This monoculture involves use of large quantities of pesticides, which has resulted in periodic mass death of fish and birds.

\section{The known record of the Colombian Grebe}

Meyer de Schauensee (1959) described the Colombian Grebe on the basis of two males collected on 31 August 1945 in Lake Tota (the type in the Academy of Natural Sciences of Philadelphia, the other in the American Museum of Natural History in New York) and an unsexed specimen labelled Sabana de Bogotá (in the U.S. National Museum, Smithsonian Institution, Washington, D.C.). The Instituto de Ciencias Naturales in Bogotá has a male and a female collected on 3 February 1939 in Lake Fúquene (by F. C. Lehmann), one male collected on 28 August 1945, five on 30 August 1945, one on 31 August 1945 and one on 9 January 1948 in Lake Tota (by J. I. Borrero), one bird collected there on 2 April 1961 (collector unknown), one collected there in January 1964 (by C. E. Stiefken) and one female with no date given (by C. E. Stiefken; this may have been taken together with the previous bird). I have examined all these specimens.

According to J. I. Hernández C. (verbally 1981) there is also one mounted bird from Lake Tota in the Museo de Universidad Pedagógico in Tunja, one in the seismological station on Isla del Santuario in Lake Fúquene and possibly one bird in a private collection.

The birds are characterized by, on average, a longer bill than the Black-necked Grebe, and by the chestnut colour of the neck and chestnut ear-plumes, the upper ones sometimes tinged golden, but never straw-yellow as in Black-necked Grebes (Meyer de Schauensee 1959). It should also be noted that no birds have similar glossy-black crown-feathers as Black-necked Grebes do, these feathers being instead slaty grey or greyish fuscous (thus tending towards the grey crown and contrasting black nape seen in the Silvery and Junín Grebes). One bird taken in February and three from August were in full breeding dress, the rest being in moult or more or less in non-breeding plumage, although always with some chestnut feathers retained (see illustrations on Plate 3 in Olivares 1969 and Plate $X$ in Fjeldså and Krabbe 1990). It should be noted that both birds from Lake Fúquene have the chestnut breast sharply demarcated from the white lower underparts, a contrast not shown by any birds from Lake Tota, suggesting a possible morphological differentiation of the populations. The measurements for the examined birds were bill 20.8-30.5, mean 27.0 $3.1 \mathrm{~mm}(n 13)$, tarsus 39-46, mean $42.5 \pm 1.7 \mathrm{~mm}$ ( $n$ 14); flattened wing-length 120-133, mean $125.3 \pm 3.1 \mathrm{~mm}(n \mathrm{16})$.

Known locally as "sira", the Colombian Grebe may once have lived all over the Bogotá wetlands. It is definitely known from the Bogotá Savanna (Laguna de la Herrera, where first recorded in 1920, Embalse del Muña, Parque la Florida 
just west of Bogotá City and La Caro north of the city (Olivares 1959, J. I. Hernández C. pers. comm.) and the Ubaté Savanna (Laguna Fúquene in the 1940s and a few birds still in the 1950s). Borrero (1947 and in litt. 1982) found it to be abundant on Lake Tota in 1945, usually in groups of 10-30 individuals. He had never seen the bird away from Lake Tota, and knew only about three birds shot between 1950 and 1970 elsewhere, by local hunters, who all regarded this as a very rare bird.

M. K. Rylander (pers. comm. to King 1978-1979) reported 300 individuals on Lake Tota in 1968 (evidence not stated). One bird was reported seen in 1972 (J. I. Hernández C. verbally), and finally "one and possibly two more" were seen in 1977 (R. S. Ridgely pers. comm. to King 1978-1979). These observations, on 13 and 15 February, represent the last reported sightings of Colombian Grebes. Although seen several hundred metres from the shore, the details given (R. S. Ridgely in litt. 1o February 1983) give little reason to doubt the identity ("one in full 'alternate plumage' with plumes but with some white mottling on the throat and foreneck"; one being similar [same bird?] and the third "with more white in the plumage ...").

Local fishermen and hunters at Lakes Tota, Cucunubá and Fúquene did not recognize the "sira" from my drawings (but few of them were knowledgeable about the identities of the birds they shot). However, the landlord and his wife of the Sta Inez inn by Lake Tota (names not recorded) recognized it and told me (convincingly, describing the habits, calls and placement of nests) about breeding colonies off Llanos los Pozos in the north-east and at Hatolaguna in the extreme north-western end of Lake Tota. These grebes were said to be very confiding and easy to shoot when nesting, as they swam out on open water when disturbed (unlike the Pied-billed Grebe Podilymbus podiceps, which skulks into vegetation cover). They were therefore shot in numbers until there were none left in these colonies. This happened in around 1965-1968.

One odd piece of information was received from Dr V. Rodríguez of INDERENA, (verbally 1981), who reported that his friend Alvaro Torres, a veterinary surgeon and knowledgeable about birds, had seen flocks of "sira" several times (but not during all visits), until "five years ago", on Laguna Cucunubá near Lake Fúquene.

Nothing is known about the biology or breeding of the Colombian Grebe, except for general statements which on no point indicate any difference from the Black-necked Grebe (J. I. Borrero in litt. and communications with the landlord at Sta Inez). Borrero (1947) mentions several females ready to lay in August. Examination of the collected specimens led me to no firm conclusions about the season of wing-moult.

\section{Field studies in 1981}

A careful study of Lake Tota, 14-28 September, was supplemented with visits to all other sites from where records of the Colombian Grebe exist, and some potential sites within its known range. Based on the record of waterbirds in 77 fairly well-studied sites, I have discussed the structure of the waterbird communities in this area (Fjeldså 1985). 


\section{The habitats of Lake Tota}

Lake Tota is surrounded by steep hills of bleak sandstones and some schists, but clayey morrains characterize the hills to the north and east. In these parts of the basin, therefore, loose sediments form some level plains, which are cultivated, with rushy meadows and some fen-like areas just inside the zones of Scirpus and Typha which fringe most of the eastern and northern coasts. Outside the widest reed-swamps in the north there are several areas with fairly extensive vegetation mosaics with mats of dense floating Bidens, Myriophyllum brasiliense and Azolla, and outside these areas the bottom is generally densely covered by monovegetation of Elodea canadense, which locally fills the water up to the surface. However, the bottoms outside the steep coasts in the west are generally gravelly and sandy without submergent vegetation. These coasts have some narrow fringing thickets of Alnus acuminata and narrow beds of Cortaderia bifida, except on exposed promontories, and these vegetation zones generally did not provide sufficient protection for grebe nests. In general, Lake Tota has clear (oligotrophic) water, although it was somewhat turbid in places where nutrients and silt were drained out from the agricultural land. Outside the Aquitania plains to the east (human population c.20,000), the Elodea vegetation was quite fouled and locally dying because of tychoplankton, especially diatoms and filamentous green algae.

Aguirre and Rangel (1976) reported that the Elodea vegetation, which they found down to $18 \mathrm{~m}$ depth locally, was mixed with Najas and with Nitella in places with a steep gradient, and these latter plants continued as a sparse vegetation down to $22 \mathrm{~m}$. Furthermore they described a community of Potamogeton illinoiensis along the more wave-exposed coasts. Also Borrero (1963) described the main submergent vegetation of the lake as being Potamogeton. Thus, between their two studies and my own, a dramatic change must have taken place from a kind of underwater vegetation which is generally quite open and surveyable to a very dense monovegetation of Elodea.

In 1981, there was a general hunting ban in Colombia, and this was reinforced quite efficiently at Lake Tota (unlike in many other areas where the police did not even know about the ban).

\section{Bird counts}

Observations of waterbirds were made at Lake Tota for 12 days, usually from sunrise till sunset. Special attention was paid to shallow bays which structurally resembled habitats of Black-necked Grebes. All parts of the lake were surveyed at least once. No Colombian Grebes were seen, and hundreds of attempts to imitate the whistled Black-necked Grebe call failed to elicit responses.

Besides this special search for Colombian Grebes I made detailed observations on the habitat selection and feeding of the Pied-billed Grebe, and of the behaviour and biosystematics of the American Coot Fulica americana columbiana (Fjeldså 1983). Finally a total census was made of the populations of waterbirds, with repeated counts in the best areas and one boat trip around the entire lake. Transect walking was discounted because the tall vegetation fringing most parts of the lake generally made it impossible to observe the lake from the shore. 
Table 1. Waterbird populations of Lake Tota, 14-28 September 1981, and according to Varty et al. (1985). Only the resident species are shown.

\begin{tabular}{lcccccccc}
\hline & $\begin{array}{c}\text { Pied-billed } \\
\text { Grebes }\end{array}$ & $\begin{array}{c}\text { American } \\
\text { Coot }\end{array}$ & $\begin{array}{c}\text { Ruddy } \\
\text { Duck }\end{array}$ & $\begin{array}{c}\text { Least } \\
\text { Bittern }\end{array}$ & $\begin{array}{c}\text { Bogotá } \\
\text { Rail }\end{array}$ & $\begin{array}{c}\text { Spot-flanked } \\
\text { Gallinule }\end{array}$ & $\begin{array}{c}\text { Purple } \\
\text { Gallinule }\end{array}$ & $\begin{array}{c}\text { Apolinar's } \\
\text { Wren }\end{array}$ \\
\hline This study & 386 ads & 800 & $60+$ & 50 & 400 & $500-600$ & c. 10 & $?$ \\
Varty et al. & 170 & 440 & 25 & $50-100$ & $30-50$ & $70-100$ & $10-20$ & $50-100$ \\
\hline
\end{tabular}

Therefore, the main method was surveying the open water and the edges of the reedbeds from suitable places on various hilltops around the lake, and from good vantage points on some of the offshore islands, using a telescope (40x). Because the lake birds were counted from far away, when undisturbed and feeding off the reed-swamp, these counts must be regarded as fairly precise (unlike the estimates based on casual records of the birds inhabiting reedswamp and fen habitats).

The total population estimates for the resident waterbirds of Lake Tota are summarized in Table 1, together with the estimates given by Varty et al. (1985), who generally saw many fewer open-water birds.

\section{Other wetlands visited}

Several other wetlands were visited briefly in the departments of Cundinamarca and Boyacá (Figure 1).

Some wetlands along the main road between Tunja and Sogamosa in Boyacá, including the hydrothermal Lago Sochacotá (examined briefly on 14 September), appeared to be strongly disturbed, with very few birds. Wetlands in the northern end of the Bogotá Savanna, near La Caro and Duitama, were almost totally drained, and the few remaining Scirpus marshes, partly overgrown oxbows and water-dams were all unsuited for Colombian Grebes. This was also the case with the strongly polluted wetlands associated with Río Bogotá at Parque de la Florida ( 3 and 5 October), near the Eldorado Airport and Las Mercedes, and a small lake at San Ramón (2-3 October). Laguna de la Herrera was one of the last remaining bird-lakes on the Bogotá Savanna. However, on my visit on 11 October 1981 it was almost drained and turned into 350 ha of marsh habitat (Scirpus) and Azolla-covered mud, with scarcely any open water.

The artificial Represa de Sisga (14 September) had barren and strongly disturbed shores and very few birds. The same was said to be true of the large artificial Embalses de Neusa (Gast 1979), Tominé and San Rafael. Embalse del Muña at the southern extreme of the Bogotá Savanna was almost dry (6 October).

Laguna de Fúquene ( $45 \mathrm{~km}^{2}$, studied 30 September-2 October) and Cucunubá $\left(3.5 \mathrm{~km}^{2}\right.$, studied 16 October) were structurally propitious for waterbirds, with complex marginal vegetation zones. However, the water quality was absolutely unsuited, as soil erosion from the deforested surrounding hills had reduced the water transparency to $0.1-0.3 \mathrm{~m}$, and almost totally eliminated the submergent vegetation (Potamogeton illinoiensis). Large populations of carp in Lake Fúquene may have added to this - see Andersson et al. (1978) for the role of especially cypriniid fishes in changing the limnic communities and accelerating the cycling 


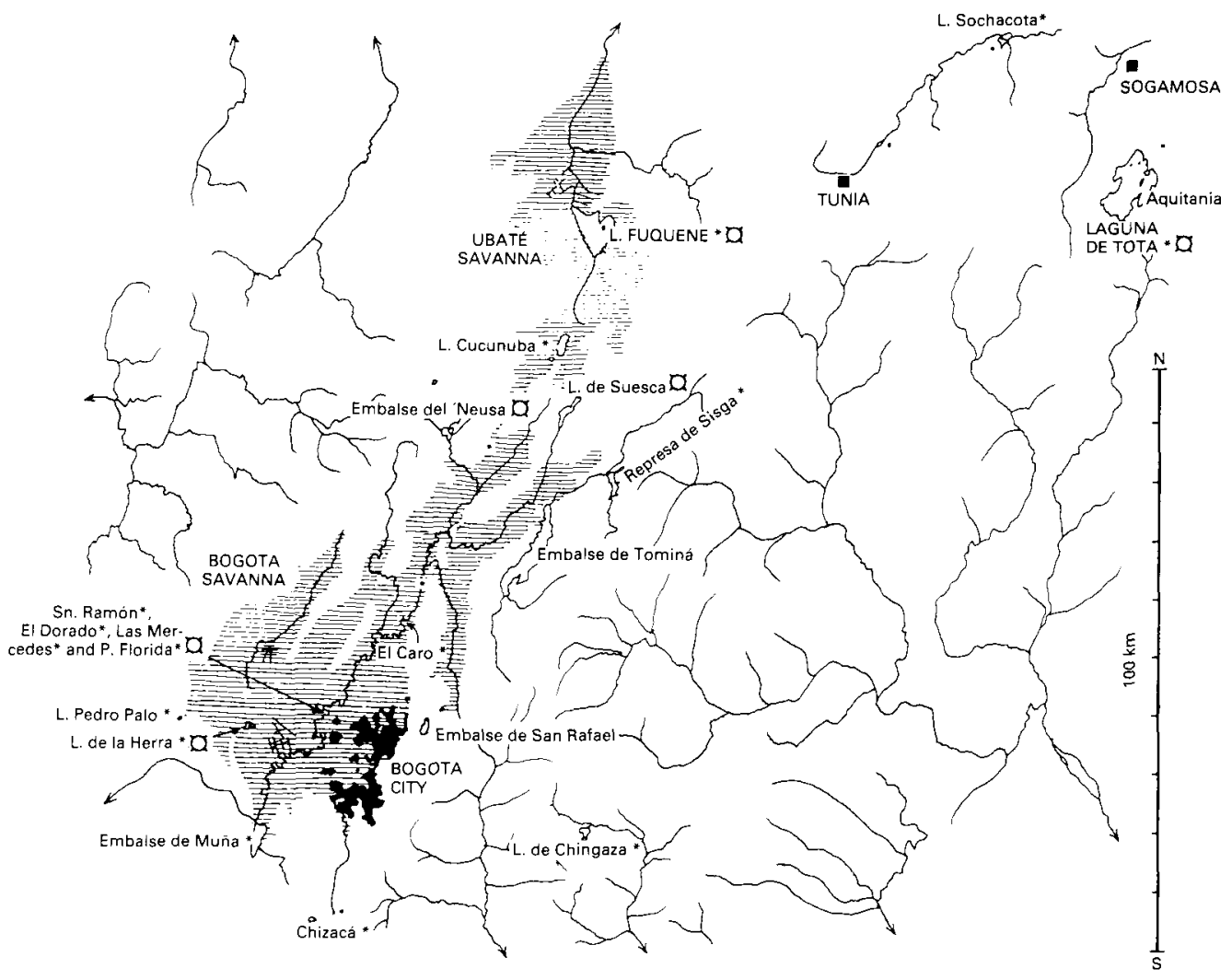

Figure 1. Lake Tota and the wetlands of the Bogotá and Ubaté Savannas (shaded) in the Eastern Andes, Colombia. Localities visited by me in 1981 are marked ${ }^{*}$, those visited by the ICBP expedition in 1982 with $a$.

of nutrients in lakes. Furthermore, the disturbing effect of indiscriminate hunting in Fúquene was appalling. Omitting marshbirds, I saw only five Least Grebes Tachybaptus dominicus and one American Coot in the large Lake Fúquene, and one Pied-billed Grebe in Lake Cucunubá. Locals told me that the lake had held lots of birds a few years ago, but they hardly recognized different species (so their information could not be used to evaluate the report of Colombian Grebes on Cucunubá from Sr Torres).

Laguna Pedro Palo in the humid subtropical zone ( 15 October) had 33 Least Grebes. Undisturbed páramo lakes at 3,300-3,700 $\mathrm{m}$ near Lake Tota ( 16 September), Chingaza east of Bogotá (9-10 October) and Chizacá south of Bogotá (6-7 October) were oligotrophic with small numbers of Speckled Teal Anas flavirostris, Ruddy Duck Oxyura jamaicensis and American Coot.

There were no signs of Colombian Grebes in any of these lakes.

\section{Food supplies}

Grebes of the Black-necked Grebe type, as well as the Australian equivalent, the Hoary-headed Grebe Poliocephalus poliocephalus, are social feeders which 
Table 2. Densities $\left(\mathrm{N} / \mathrm{m}^{3}\right)$ of macroinvertebrates outside the reedbeds of Lakes Tota and Fúquene, compared with similar data from feeding zones of grebes which show similar feeding adaptations as the Colombian Grebe, namely: a breeding area for Silvery Grebes Podiceps occipitalis in the south of Lake Junín and three breeding areas in Puno, Peru; and two breeding areas for Hoary-headed Grebes Poliocephalus poliocephalus in New South Wales, Australia. In each study area, samples were taken in 5-10 microhabitats. The food supply was studied in the same way in all four studies (see Fjeldså 1981, 1988) by pulling a plankton-net ( $40 \mathrm{~cm}$ diameter, $0.2 \mathrm{~mm}$ mesh) a recorded distance through the submergent vegetation in places where grebes used to feed. Large Cladocera and Ostracoda were counted but, because it is difficult to draw a sharp limit towards the smaller forms of zooplankton, only relative abundance $(+-+++)$ of micro- and macrozooplankton is given here. In Lake Tota, samples were taken in various kinds of submergent vegetation or below floating carpets of Azolla and Myriophyllum in the north (off Llanos los Pozos and in Hatolaguna) and in submergent Elodea vegetation off the east coast (Sta Inez and off Aquitania). In Lakes Cucunubá and Fúquene there was virtually no submergent vegetation.

\begin{tabular}{|c|c|c|c|c|c|c|c|c|}
\hline & \multirow{2}{*}{$\begin{array}{c}\mathrm{m}^{3} \\
\text { sampled }\end{array}$} & \multicolumn{2}{|c|}{ Zooplankton } & \multirow[b]{2}{*}{ Amphipods } & \multirow{2}{*}{$\begin{array}{l}\text { Midge } \\
\text { larvae }\end{array}$} & \multirow[b]{2}{*}{ Bugs } & \multirow{2}{*}{$\begin{array}{l}\text { Other } \\
\text { insects }\end{array}$} & \multirow[b]{2}{*}{ Snails } \\
\hline & & micro & macro & & & & & \\
\hline N Lake Tota & 4.0 & + & + & 420 & 69 & 17 & 2 & 6 \\
\hline E Lake Tota & $4 \cdot 5$ & +++ & + & 15 & 85 & 0.3 & 2 & 6 \\
\hline \multicolumn{9}{|l|}{ Cucunubá + } \\
\hline Fúquene & 4.0 & +++ & ++ & - & - & - & - & - \\
\hline Lake Junín & 4.2 & + & +++ & 11 & 82 & 140 & 6 & 1 \\
\hline Puno lakes & 4.6 & ++ & + & 818 & 455 & 107 & 19 & 143 \\
\hline New South Wales & 8.6 & + & +++ & 54 & 32 & 58 & 22 & 3 \\
\hline
\end{tabular}

select prey on the basis of its abundance and availability, with no great regard to its size (Fjeldså 1981, 1983, 1986, 1988). This requires that the prey is present in high densities and in fairly open and surveyable underwater microhabitats, mainly in extensive shallows with a rather dispersed vegetation of water-weeds, of which linear-leaved and light types of Potamogeton, Ruppia etc. appear to be favoured. Because grebes feeding young bring one prey at a time, a plentiful supply of fair-sized arthropods, such as amphipods, damselfly larvae and bugs (especially Corixidae), are required in this period. The fairly long bill of the Colombian Grebe, approaching the condition in the Junín Flightless Grebe Podiceps taczanowskii (see Fjeldsa 1981), suggests that it would be able to take small specimens of the native fishes Eremophilus mutissii and Grunoulus bogotensis.

Table 2 compares calculated densities of macrofauna in the potential feeding zones of Colombian Grebes in Lakes Cucunubá, Fúquene and Tota, and in feeding microhabitats used by breeding colonies of Silvery and Hoary-headed Grebes (see legend for explanation). In general, the densities of insects, except larvae of chironomid midges, were very low in Lake Tota compared with the breeding habitats of other colony-breeding grebes (see also data from semiquantitative sweep-net samples in Lake Tota in Varty et al. 1985). Also the density of large Cladocera was low (as the zooplankton was dominated by tiny species of the family Chydoriidae), but in the northern end of the lake (Hatolaguna) amphipods were common below floating carpets of Azolla. In general, places with similar low invertebrate densities as found in Lake Tota will 
only have grebes which feed mainly by stalking fish (see Table 6 in Fjeldså 1991). It must be added to this that it would be energetically expensive for birds of the Black-necked Grebe type to work their way through the very dense Elodea vegetation and find prey in its dense and "curly" foliage.

I conclude that the present Elodea zones of Lake Tota have now become unsuitable for breeding colonies of grebes of the Black-necked Grebe type. The Pied-billed Grebe is more suited to cope with this situation, since it is well adapted to feed inside dense vegetation, in fairly open parts of the reed-swamp, and diving right through the Elodea masses, where it hunts a wide variety of prey, often emerging with dragonfly larvae, fish and even crabs Potamocarcinus (Hypolobocera) macropus in its bill. High densities of amphipods, bugs, odonate larvae, etc., were found in some ditches and narrow channels inside the reedbeds at Lakes Tota and Fúquene, but these enclosed habitats would not be used by birds of the Black-necked Grebe type.

Samples taken off the reed-swamps in the turbid waters of Lakes Fúquene and Cucunubá contained nothing but copepods and cladocerans (Table 2)!

\section{Conclusions of the ICBP expedition 1982}

No Colombian Grebes were found, and the expedition members met no fishermen who were familiar with the Black-necked Grebe type of bird. Varty et al. (1985) concluded that the area had generally lost its value for lake birds, and their report therefore concentrated on data and management plans for the marshbirds, of which viable populations still remained.

The main study site was Lake Tota, but visits were also made to Laguna de la Herrera, Parque de la Florida, Laguna de Fúquene, Laguna de Suesca and Embalse de Neusa.

\section{Discussion}

Reasons for the decline of the Colombian Grebe

The disappearance of the Colombian Grebe from the Bogotá and Ubaté Savannas is primarily a consequence of the draining of the majority of wetlands and of the complete mismanagement of those that remain. Most wetlands today lack significant sheets of open water, and these areas, hypereutrophic or opaque by suspended silt, no longer provide the abundance of macroinvertebrates required by the Black-necked Grebe type of bird. Lake Tota is still a good area for many reed-swamp birds, gallinules, coots and Pied-billed Grebes. However, the populations of Colombian Grebe and Nicéforo's Pintail Anas (georgica) niceforoi, which both may have preferred extensive shallows with a rather open type of submergent vegetation, vanished in the course of the 1950 os and 1960 . At the same time the wetlands in the Eastern Andes of Colombia lost their status as an important wintering area for Nearctic waterfowl (J. I. Hernández C., pers. comm.). The population in the Eastern Andes of Colombia of the rare Southern Pochard Netta erythrophthalma largely vanished in the 1940s, and the local subspecies of Cinnamon Teal Anas cyanoptera borreroi has been reduced to very small numbers. 
Four main theories have been advanced to account for the demise of the Colombian Grebe (Borrero 1963, King 1978-1979): poisoning of birds by pesticides used in the intensive agriculture on the Aquitania Plains near Lake Tota; disruption of breeding by reed harvesting; hunting; and predation of chicks by rainbow trout Salmo gairdneri (introduced in 1944).

Varty et al. (1985) pointed out as a probably more important factor that Lake Tota no longer has the extensive Potamogeton vegetation described by Borrero (1963). The Elodea beds have modest densities of invertebrates (Table 2) and may, with their very dense foliage, have been unsuitable for feeding Colombian Grebes. Sudden changes in water levels in the 1940s may have meant some failed breeding years for the grebes, and the permanent lowering of the water levels meant loss of fine shallow-water breeding and feeding habitats off Aquitania. Because straight channels were dug to drain the reclaimed areas, sewage and silt was washed right into the lake instead of being absorbed by the reedswamp. Possibly, the resulting eutrophication led to a change of the limnic community towards one dominated by a few species of worms, chironomid midges and tiny waterfleas, of low value for the Colombian Grebe. The population decline of the endemic birds started well before the intensive onion cultivation and the massive use of insecticides (J. I. Hernández C., pers. comm.).

R. S. Ridgely and J. I. Hernández C. (in King 1978-1979) believed that the initial cause of the decline of the grebe population in Lake Tota was the introduction of trout. Apparently, the endemic "fat fish" Tricomiterus totai disappeared at around the same time. The trout has now been strongly overfished, and Varty et al. (1985) considered that "if fish were competitors with waterbirds for food, the competition was certainly only minimal at the time" $e^{\prime \prime}$ However, the main effect of trout may be more subtle, as it gradually selects for another limnic community with mainly microzooplankton in the open microhabitats (see Hurlbert et al. 1986 for the effect of trout on former flamingo lakes in the puna zone), restricting the macroinvertebrates to dense vegetation cover. The presence of a moderate trout population may therefore maintain a limnofauna which, combined with a new structure of submergent vegetation, would make the remaining food resources partly inaccessible for Colombian Grebes.

R. S. Ridgely (in litt. and in King 1978-1979) and Varty et al. (1985) did not regard hunting as a serious factor, as there were still good populations of more attractive game. Nevertheless, direct testimony (see above) indicates that Colombian Grebes had been hunted selectively, and that this may have played a critical role at the time when other factors had already reduced the population to a few colonies. I assume that the Colombian Grebe was a prudent breeder that maintains the necessary life-time reproduction by survival adaptations more than by investing energy in raising many young. This is to some degree the case in the Black-necked Grebe, and its Andean relatives have carried this to an extreme by normally having only one annual clutch of two eggs (Fjeldså 1986). Shooting of the adult individuals would have a particularly serious impact on birds with this kind of life strategy (compared with the multiple-brooded Pied-billed Grebes and American Coots).

Borrero (1963) pointed out that the grebe could have been disturbed by reedharvesting. This is an immediately conspicuous threat, but may be relatively insignificant in view of the species's life-history strategy, and since grebes of 
the Black-necked/Silvery types manage perfectly well without tall reeds by placing their nests in extensive carpets of floating waterweeds instead. Lake Tota still has sufficient reed-swamp vegetation for strong populations of Pied-billed Grebes, Spot-flanked Gallinules Gallinula melanops and American Coots (which all prefer thick vegetation cover).

\section{Is the Colombian Grebe extinct?}

With the surveys in 1981 and 1982, all wetlands in the Eastern Andes of Colombia have been visited, except for tiny inundations and páramo lakes which in general seem to be too unproductive for birds of the Black-necked Grebe type.

Varty et al. (1985) concurred with Campezano (1960) and Borrero (1963) that the Colombian Grebe was "extinct for perhaps the last 20 years", and proposed that the records in the 1960s and 1970s should be subject to scrutiny. However, I find no reason to doubt in the observations by $R$. S. Ridgely. In view of the information from the landlord of the Sta Inez inn, I suggest that a few colonies remained for some time after the main "crash" in the 1950s, and that a very few individuals escaped the shooting in the breeding colonies and survived until the late 1970 .

It seems clear that the Colombian Grebe has now disappeared from all its known haunts. Therefore, if any additional searches are to be made (as part of general surveys for assessing the conservation value of Andean lakes), these should target as yet unexplored areas. The information about flocks in Laguna Cucunubá in the 1970s, if credible, offers the slight hope that a group of birds may have been wandering around, maybe after their traditional haunts had become unsuitable for breeding. Black-necked Grebes are well known for making erratic population movements (see Frieling 1933 and Kalela 1946, in particular). Data from some breeding colonies in Denmark (several reports of limited circulation) suggest that a failed breeding year may often be a stimulus for moving elsewhere. Although unable to raise young in disturbed lakes with low densities of macroinvertebrates, straggling Colombian Grebes would probably survive for years and could possibly settle somewhere else. The final question is therefore whether suitable lakes exist at all today in the northern parts of the Andes. Páramo lakes north of the known range, at the head of Rio Casanare (Lagunas Ocubi) and in Sierra Nevada de Güicán (Cocuy), or even further north in Santander, are probably too small and unproductive. The larger páramo lakes in the Central Andes are currently occupied by the closely related Silvery Grebe Podiceps occipitalis, but the longer bills of the Colombian Grebe may permit coexistence in good feeding habitats with an abundance of tiny fish (see Fjeldså in press).

\section{Conservation measures for the Bogota wetlands}

Varty et al. (1985) concluded that Lake Tota and the Bogotá wetlands have lost their value for lake-birds, and that conservation work should now focus on the special reed-swamp avifauna (Least Bittern Ixobrychus exilis bogotensis, Bogotá Rail Rallus semiplumbeus, Spot-flanked Gallinule Gallinula melanops bogotensis, Apolinar's Marsh-wren Cistothorus apolinari and Yellow-hooded Blackbirds Age- 
laius icterocephalus bogotensis - see Table 1; Bearded Tachuri Polystictus pectoralis bogotensis could also be mentioned). This would above all require some management of water levels and regulation of the utilization of the vegetation of the fens and reed-swamps.

Although the Colombian Grebe and Niceforo's Pintail are now highly probably extinct, there is still some motive for protecting the habitat of other birds which mainly feed outside the reed-swamp. Proper hunting regulations and improved water quality might bring some Nearctic waterfowl back to the region and would help the endemic subspecies of Ruddy Duck (race andina) and American Coot (race columbiana) and the few remaining Cinnamon Teal (race borreroi). S. Rønnest (in litt. 1987) saw four Southern Pochards in 1986 on a clear lake with rich submergent vegetation (Tamagata at 2,000 $\mathrm{m}$, west of the Bogotá Savanna).

It is now well documented that the productivity of wetlands, their effects in maintaining ground-water levels, stabilizing the climate and acting as sinks of nutrients and contaminants, often represent far greater economic benefits than those obtained by converting them, although in more indirect and long-term ways (Maltby 1986). The "developers" of the Bogotá and Ubaté Savannas did not have this knowledge, and I would hardly expect that the motivation or economic basis will ever exist for wetland restoration on any significant scale for these areas. However, for some of the lakes small improvements may still be possible if the water levels are managed properly and something is done to reduce the contamination and siltation. The above-mentioned conservation of the marsh vegetation may in fact be a useful measure also for securing the quality of the open-water areas. Limnobium, an important floating plant in most lakes of the Bogotá and Ubaté Plateaus, would have the same effect as the better-known water hyacinth Eichornia crassipes in reducing eutrophication (but not siltation). If the straight channels that now lead fertilizers and silt right into the wetlands are blocked, letting the water seep through the marshland, or re-establish a meandering course, the root zone will retain the pollutants, leading to improved water quality.

\section{Acknowledgements}

My study was supported by Grant No. 11-2250 from the Danish Natural Science Research Council and by the G. E. C. Gads Foundation, Knud Højgaards Foundation and Queen Margrethe and Prince Henrik's Foundation. My thanks are due to Ole Høegh Post and Else Bering for their assistance. Enrique Zerda O., Ana Victoria Ayala R., José Gregorio Moreno, Ricardo López Briceño, Jesús Ernesto Pachón, Milton Riano Díaz and others participated on various fieldtrips. I thank Nigel Collar, Philip J. Espin and Nigel Varty for stimulating correspondence over the ICBP expedition of 1982. My thanks are also due to INDERENA in Bogotá, especially Carlos Cruz for logistical assistance and Dr Jorge Hernández Camacho for a wealth of information about the natural history of the Bogotá area. 


\section{References}

Aguirre C., J. and Rangel C., O. (1976) Contribución al estudio ecológico y fitosociológico de las communidades acuáticas macroscópicas y continentales de Laguna de Tota y alrededores. Bogotá: Universidad Nacional de Colombia, Facultad de Ciencias (thesis).

Andersson, G., Berggren, H., Cronberg, G. and Gelin, C. (1978) Effects of planktivorous and benthivorous fish on organisms and water chemistry in eutrophic lakes. Hydrobiologia 59: 9-15.

Blake, E. R. (1977) Manual of Neotropical birds, 1. Chicago: University of Chicago Press.

Borrero, J. I. (1947) Aves ocasionales en la sabana de Bogotá y las lagunas de Fúquene y de Tota. Caldasia 4: 495-498.

Borrero, J. I. (1963) El Lago de Tota. Rev. Fac. Nac. Agron. 23: 1-15.

Campezano, M. (1960) El Lago de Tota. Bogotá: Universidad de Bogotá.

C.A.R. (Corporación Autónoma Regional de la Sabana de Bogotá) (1978) Estudio de conservación y manejo del Lago de Tota y su cuenca. Bogotá: Hidroestudios, Ingenieros Consultores.

Collar, N. J., Gonzaga, L. P., Krabbe, N., Madröno Nieto, A., Naranjo, L. G., Parker, T. A. and Wege, D. C. (1992) Threatened birds of the Americas: the ICBP/IUCN Red Data Book. Cambridge, U.K.: International Council for Bird Preservation.

Fjeldså, J. (1981) Comparative ecology of Peruvian grebes - a study of the mechanisms of evolution of ecological isolation. Vidensk. Meddr. dansk naturh. Foren. 144: 125-249.

Fjeldså, J. (1982) Systematic and biological notes on the Colombian Coot Fulica americana columbiana (Aves, Rallidae). Steenstrupia 9: 209-215.

Fjeldså, J. (1983) Character displacement and character release in grebes, Podicipedidae. Ibis 125: 463-481.

Fjeldså, J. (1985) Origin, evolution and status of the avifauna of Andean wetlands. Pp.85112 in P. A. Buckley, M. S. Foster, E. S. Morton, R. S. Ridgely and F. G. Buckley, eds. Neotropical ornithology. Washington, D.C.: American Ornithologists' Union (Orn. Monogr. 36).

Fjeldså, J. (1986) Feeding ecology and possible life history tactics of the hooded grebe Podiceps gallardoi. Ardea 74: 40-58.

Fjeldså, J. (1988) Comparative ecology of the Australasian grebes (Aves: Podicipedidae). RAOU Report no. 54 .

Fjeldså, J. (in press) Niche segregation of grebes and other diving birds of temperate freshwater habitats, worldwide: do parallel communities evolve? Proc. 7 Nordic Orn. Congr.

Frieling, H. (1933) Die Ausbreitung des Schwarzhalstauchers, Podiceps nigricollis nigricollis Brehm: ein Beitrag zur kausalanalytischen und vergleichenden Tiergeographie. Zoogeographica 1: $485-550$.

Gast, A. (1979) Biotic comparisons of native and non-native plant communities at Neusa, Cundinamarca, with an avian emphasis. Bogotá: Corporacion Autónoma Regional.

van Geel, B. and van den Hammen, T. (1973) Upper Quarternary vegetational and climatic sequences of the Fúquene Area (Eastern Cordillera, Colombia). Palaeogeogr. Palaeoclimatol. Palaeoecol. 14: 9-92.

Hernández C., J. (1980) Extinción y peligro de extinción en la fauna silvestre de Colombia. Reunión Iberoam. Zool. Vertebr. I(1977): 73.

Hooghiemstra, H. (1991). Long continental pollen record from a tropical intermontane basin: Late Pliocene and Pleistocene history from a 540-meter core. Episodes 14: 107115.

Hurlbert, S. H., Loayza, W. and Moreno, T. (1986) Fish-flamingo-plankton interactions in the Peruvian Andes. Limnol. Oceanogr. 31: 457-468.

Kalela, O. (1946) Zur Ausbreitungsgeschichte der Vögel vegetationsreicher Seen. Ann. Acad. Sci. Fenn. Ser. A, IV, Biol. 12: 1-81. 
King, W. B. (1978-1979) Red data book, 2: Aves. Second edition. Morges, Switzerland: International Union for Conservation of Nature and Natural Resources.

Maltby, E. (1986) Waterlogged wealth: why waste the world's wet places? London: Earthscan. Meyer de Schauensee, R. (1948-1952) The birds of the Republic of Colombia. Caldasia 5(22): 251-380; (23): 381-644; (24): 645-871; (25): 873-1112; (26): 1115-1214.

Meyer de Schauensee, R. (1959) Additions to the birds of the Republic of Colombia. Proc. Acad. Nat. Sci. Philadelphia 111: 53-75.

Olivares, A. (1969) Aves de Cundinamarca. Bogotá: Dirección de Divulgación Cultural.

Simmons, K. E. L. (1962) Some recommendations for a revised check-list of the genera and species of grebes (Podicipedidae). Bull. Brit. Orn. Club 82: 109-116.

Storer, R. W. (1979) Order Podicipediformes. Pp.140-155 in E. Mayr and G. W. Cottrell, eds. Check-list of birds of the world, 1. Second edition. Cambridge, Mass.: Museum of Comparative Zoology.

Varty, N., Adams, J., Espin, P. and Hambler, C. (1985) An ornithological survey of Lake Tota, Colombia, 1982. Cambridge, U.K.: International Council for Bird Preservation (Study Report 12).

\section{JON FJELDS $\AA$}

Zoological Museum, University of Copenhagen, Universitetsparken 15, DK-210o Copenhagen, Denmark. 